\title{
Effect of hot air and freeze drying on the volatile compounds of dill (Anethum graveolens L.) herb
}

\author{
RAINER HUOPALAHTI, EILA KESÄLAHTI and REINO LINKO \\ Department of Chemistry and Biochemistry, Laboratory of Food Chemistry, \\ University of Turku, SF-20500 Turku, Finland
}

\begin{abstract}
Volatile compounds of fresh, hot air dried and freeze dried dill (Anethum graveolens L.) herb were studied by gas chromatography-mass spectrometry. Of the 25 volatile components identified, 16 the most abundant compounds were analysed quantitatively. The major primary aroma compounds were $\alpha$-phellandrene, 3,6-dimethyl-2,3,3a,4,5,7ahexahydrobenzofuran, $\beta$-phellandrene, limonene, $\alpha$-pinene, $\mathrm{p}$-cymene and myristicin. Severe loss of these components occured during the drying of dill. E.g. the retention of the benzofuranoid, the most important aroma component of the dill herb, was from trace to $1.3 \%$ in hot air dried samples and 3.5-20\% in freeze dried samples. During the drying secondary aroma compounds are formed consisting over $50 \%$ of the total volatiles. Among these phytadienes, especially neophytadiene, were the major components. The best result was obtained by freeze drying, but the product contained only one quarter of the total aroma compounds of the fresh dill herb.
\end{abstract}

\section{Introduction}

Dill is used in Finland and in other Scandinavian countries mainly as fresh aerial part of the plant before the bud formation or at the flowering stage (dill herb) as well as also in smaller amounts as frozen or dried chopped dill leaves.

The composition and content of aroma compounds in the fresh dill herb have been studied by Huopalahti et al. (1981), SCHreier et al. (1981), Huopalahti and Linko (1983), and Huopalahti (1985 a,b).

However, it is well known that the quality of dill undergoes great changes during process- ing and subsequent storage. Thus a decrease in the total aroma content was observed in frozen dill, already after about two months storage at $-20^{\circ} \mathrm{C}$ depending on the packaging material (HuOPalahtı, 1985 c). Also a preliminary work of DRAWERT et al. (1981) showed severe losses of aroma compounds during drying of the dill herb. On the other hand, using conventional air drying with high frequence heating ZAUSSIGER (1975) found that although the dried dill was of high quality, a specific flavour and taste were developed.

The present work was undertaken to study the composition and content of volatile sub-

Index words: drying, dill, volatile 
stances in the dill herb at an early stage of maturity after drying with hot air at different temperatures and after freeze drying. Special attention was paid to the secondary aroma compounds formed by degradation of plant pigments.

\section{Materials and methods}

\section{Materials}

The dill (Anethum graveolens L. 'Mammut' WW) was cultivated in Central Finland (Sahalahti, 61 ${ }^{\circ} 29^{\prime}$ N.lat.) on a prefertilized light sphagnum peat, huminocity $1-3$ (Finn peat, ST-400-82). The dill was harvested before the bud formation and dried with hot air (by fan) or freeze dried. Both apparatus were conventional systems in the laboratory scale. The drying conditions are presented in Table 1. The dried dill samples were packed into Aluminium foil laminate (HuOPALAHTI, 1985 c) and stored at room temperature. Fresh or dried dill samples were chopped by cutting before analyses, which were carried out immediately after harvesting or within a few days storage after processing and packaging.

\section{Isolation of volatile compounds}

Volatile compounds were isolated by extracting 45 grams of fresh or 10 grams of dried dill for six hours with $350 \mathrm{ml}$ of the mixture of redistilled n-pentane and diethyl ether $(1: 2, \mathrm{v} / \mathrm{v})$ by using a modified Soxhlet- tecnique. The extract was concentrated at $35^{\circ} \mathrm{C}$, with a Widmer column, to the volume of $2 \mathrm{ml}$. The purification of the concentrate was carried out at $10^{\circ} \mathrm{C}$ on a column packed with silica gel as described by SCHEFFER et al. (1977). Detailed information is available in our previous paper (HuOPALAHTI and LinKo, 1983).

\section{Gas chromatographic and mass spectrometric analyses}

The GC-analyses of the volatile concentrates were carried out on a Varian 3700 gas chromatograph equipped with a flame ionization detector connected to a Hewlett Packard 3388A integrator. The fused silica column (0.32 i.d. $\times 25 \mathrm{~m}$; film thickness $0.20 \mu \mathrm{m}$ ) coated with OV-351 and temperature programming at the rate of $2{ }^{\circ} \mathrm{C} / \mathrm{min}$ from 70 to $230^{\circ} \mathrm{C}$ after an isothermal period of $2 \mathrm{~min}$, was applied for the separations. The flow rate of the carrier gas (nitrogen) was $1.5 \mathrm{ml}$ / $\min$.

The $70 \mathrm{eV}$ EI mass spectra were obtained on a VG Analytical $7070 \mathrm{E}$ instrument by using the same capillary column as in the GC-analysis.

The quantitative estimations of volatile compounds were performed by using linalool as the internal standard. In the calculation of the total volatile content 70 peaks of each chromatogram were summed up. The presented values are mean values from double determinations.

Table 1. Drying conditions and characteristics of fresh, air dried and freeze dried dill.

\begin{tabular}{|c|c|c|c|c|c|}
\hline \multirow[t]{2}{*}{ Dill } & \multirow{2}{*}{$\begin{array}{c}\text { Drying } \\
\text { temperature } \\
\left({ }^{\circ} \mathrm{C}\right)\end{array}$} & \multirow{2}{*}{$\begin{array}{l}\text { Duration } \\
\text { of drying } \\
\text { (hr) }\end{array}$} & \multirow{2}{*}{$\begin{array}{l}\text { Moisture } \\
\qquad(\%)\end{array}$} & \multicolumn{2}{|c|}{$\begin{array}{c}\text { Total amount of } \\
\text { volatile compounds }\end{array}$} \\
\hline & & & & $\begin{array}{l}\text { (mg/100 g } \\
\text { dry weight) }\end{array}$ & $(\%)$ \\
\hline Fresh & - & - & 90 & 326 & 100 \\
\hline Air dried & 25 & 26 & 11 & 49 & 15 \\
\hline Air dried & 40 & 8 & 10 & 29 & 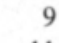 \\
\hline Air dried & 50 & 4 & 12 & 37 & 11 \\
\hline Freeze dried 1 & -25 & 59 & 16 & 188 & 58 \\
\hline Freeze dried 2 & -25 & 65 & 2 & 83 & 25 \\
\hline
\end{tabular}




\section{Results and discussion}

The spice industry aims to maintain its products at less than $14 \%$ moisture to prevent spoilage by molds and above $5 \%$ to avoid crumbling and loss of shape (SснміDT, 1975).

In the present study the dill herb was dried in hot air at three different temperatures to reach an average moisture content of about $11 \%$ (Table 1). The drying time varied from $26 \mathrm{~h}$ at $25^{\circ} \mathrm{C}$ to $4 \mathrm{~h}$ at $50^{\circ} \mathrm{C}$. The duration of drying depends also on the relative humidity of the air passed through the drying chamber. In the freeze drying experiments it was much more difficult to regulate the moisture content of the product. Therefore after freeze drying of 59 hours the moisture content was still $16 \%$, while it during additional drying of 6 hours decreased to the level of $2 \%$ (Table 1).

Table 1 shows that the total amount of volatiles in the fresh dill herb, with the moisture content of $90 \%$, was about $330 \mathrm{mg}$ / $100 \mathrm{~g}$ dry weight. However, it diminished drastically during hot air drying and was only $9-15 \%$ of the volatiles of the fresh dill herb. Moreover, over a half of the total volatiles of the air dried dill were apparently sec-

Table 2. Mass spectral data of identified phytadienes.

\begin{tabular}{|c|c|c|c|c|c|c|}
\hline Compound & $\begin{array}{l}\text { Parent peak } \\
\left(\mathrm{M}^{+}, \text {rel int.) }\right.\end{array}$ & $\begin{array}{l}\text { M/e } \\
\text { (rel int.) }\end{array}$ & & & & \\
\hline $\begin{array}{l}\text { Neophytadiene } \\
(7,11,15 \text {-trimethyl-3- } \\
\text { methylene-1-hexadecane) }\end{array}$ & $278(4)$ & $\begin{array}{l}68(100), \\
43(69), \\
71(43),\end{array}$ & $\begin{array}{l}57(81), \\
55(63), \\
67(41),\end{array}$ & $\begin{array}{r}82(79), \\
41(59), \\
123(38)\end{array}$ & $\begin{array}{l}95(75), \\
81(51) \\
97(34)\end{array}$ & $\begin{array}{r}69(70) \\
83(51) \\
109(24)\end{array}$ \\
\hline $\begin{array}{l}\text { 1,3-Phytadiene } \\
(3,7,11,15 \text {-tetramethyl- } \\
\text { 1,3-hexadecadiene })\end{array}$ & $278(10)$ & $\begin{array}{l}82(100), \\
69(56), \\
71(47),\end{array}$ & $\begin{array}{l}81(97), \\
43(54), \\
41(44),\end{array}$ & $\begin{array}{r}95(83), \\
123(54), \\
96(36)\end{array}$ & $\begin{array}{l}57(78) \\
55(50) \\
97(36)\end{array}$ & $\begin{array}{r}68(78) \\
83(49) \\
109(30)\end{array}$ \\
\hline $\begin{array}{l}\text { 2,4-Phytadiene } \\
\text { (3,7,11,15-tetramethyl- } \\
\text { 2,4-hexadecadiene) }\end{array}$ & $278(16)$ & $\begin{array}{l}82(100), \\
69(57), \\
71(45),\end{array}$ & $\begin{array}{l}81(96), \\
43(54), \\
41(44),\end{array}$ & $\begin{array}{r}95(86), \\
123(52), \\
98(40)\end{array}$ & $\begin{array}{l}57(79), \\
83(52), \\
97(38),\end{array}$ & $\begin{array}{r}68(74) \\
55(47) \\
109(33)\end{array}$ \\
\hline
\end{tabular}

Table 3. Concentrations of volatile components ( $\mathrm{mg} / 100 \mathrm{~g}$ dry weight) of fresh, hot air dried and freeze dried dill.

\begin{tabular}{|c|c|c|c|c|c|c|}
\hline \multirow[t]{2}{*}{ Component } & \multirow[t]{2}{*}{ Fresh } & \multicolumn{3}{|c|}{ Dried with hot air } & \multicolumn{2}{|c|}{ Freeze dried } \\
\hline & & $25^{\circ} \mathrm{C}$ & $40^{\circ} \mathrm{C}$ & $50^{\circ} \mathrm{C}$ & 1 & 2 \\
\hline$\alpha$-Pinene & 5.8 & 1.2 & 0.6 & 1.4 & 3.1 & 0.6 \\
\hline Terpinolene & 0.4 & 0.4 & 0.4 & 0.2 & 0.3 & 0.5 \\
\hline$\beta$-Pinene & 1.2 & 0.5 & 0.4 & 0.4 & 0.5 & 0.5 \\
\hline$\alpha$-Phellandrene & 198.1 & 13.3 & 6.1 & 8.1 & 41.6 & 14.9 \\
\hline Limonene & 10.0 & 0.7 & 0.3 & 0.4 & 2.0 & 0.7 \\
\hline$\beta$-Phellandrene & 27.5 & 2.2 & 0.9 & 1.1 & 6.5 & 1.8 \\
\hline$\gamma$-Terpinene & 0.2 & $\operatorname{tr}$ & $\operatorname{tr}$ & $\operatorname{tr}$ & tr & $\operatorname{tr}$ \\
\hline p-Cymene & 5.5 & 1.1 & 0.3 & 0.4 & 4.0 & 0.1 \\
\hline \multicolumn{7}{|l|}{ 3,6-Dimethyl-2,3,3a,4,5, } \\
\hline 7a-hexahydrobenzofuran & 39.8 & 0.5 & $\operatorname{tr}$ & $\mathrm{tr}$ & 8.9 & 1.4 \\
\hline$\alpha$-Terpineol & 1.2 & 0.2 & 0.1 & $\mathrm{tr}$ & 0.6 & 0.2 \\
\hline Carvone & $\operatorname{tr}$ & $\operatorname{tr}$ & $\mathrm{tr}$ & $\mathrm{tr}$ & $\operatorname{tr}$ & 0.2 \\
\hline Myristicin & 4.4 & 0.6 & 0.3 & 0.3 & 4.3 & 1.5 \\
\hline n-Undecane & 0.6 & tr & $\mathrm{tr}$ & $\operatorname{tr}$ & 0.3 & tr \\
\hline Neophytadiene & 1.0 & 6.3 & 3.9 & 2.6 & 38.2 & 26.0 \\
\hline 1,3-Phytadiene & 0.2 & 0.5 & 0.3 & 0.8 & 4.8 & 3.8 \\
\hline 2,4-Phytadiene & 0.3 & 0.8 & 0.5 & 1.0 & 6.5 & 0.6 \\
\hline
\end{tabular}

$\mathrm{tr}=$ in trace amounts $<0.1 \mathrm{mg} / 100 \mathrm{~g}$ dry weight. 
ondary aroma compounds as can be seen from the results presented later (see Table 3). Although the moisture content of the freeze dried dill differed from that of the air dried products, the former contained more total volatiles than the latter ones (Table 1). Thus $25-58 \%$ of volatiles remained in the freeze dried dill depending on the drying time. Also in this case over a half of the total volatiles consisted of secondary aroma compounds (see Table 3). The best product obtained in this experiment by freeze drying contained only one quarter of the total aroma compounds of the fresh dill herb.

Dill is evidently very susceptible to losses and changes of aroma compounds during drying compared e.g. to parsley KARAWYA et al., 1980) and laurel leaves (BYrON, 1982), in which case no significant changes in the amounts of essential oil were found in hot air drying.

According to DRAwERT et al. (1981) among the aroma compounds of plants the primary or genuine aroma compounds present in natural plant cells can be distinguished from secondary aroma compounds formed in technical processes or by enzymatic action dyring pretreatments.

The same 22 aroma compounds identified earlier in the dill herb at an early stage of maturity (HuOPAlahti et al., 1981, HuopaLAHTI and LINKO, 1983) were found in this study, too. In addition three secondary aroma compounds neophytadiene, 1,3-phytadiene and 2,4-phytadiene could be identified. Their mass spectral data are presented in Table 2.

The concentrations of 16 volatile components of the fresh dill herb and of different dried dill products (see Table 1) are presented in Table 3.

In the fresh dill herb $\alpha$-phellandrene, 3,6-dimethyl-2,3,3a, 4,5,7a-hexahydrobenzofuran, $\beta$-phellandrene, limonene, $\alpha$-pinene, $\mathrm{p}$ cymene and myristicin were the main aroma components. Of these compounds in addition to the benzofuranoid, the character impact compound of the dill herb, also $\alpha$-phellan- drene, limonene and p-cymene have been earlier found to contribute to the overall aroma of the herb (HuOPAlahti, 1985 a). However, the concentration of the last mentioned aroma components diminished greatly during the hot air drying of dill. Thus e.g. of the content of the major compounds of the fresh dill herb, $\alpha$-phellandrene and the benzofuranoid, only $3.1-6.7 \%$ and $\operatorname{tr}-1.3 \%$, respectively, were left in the air dried dill products. On the other hand, their retention in the freeze dried products was somewhat better. The product with the higher moisture content (sample 1) contained both $\alpha$-phellandrene and the benzofuranoid about $20 \%$ of the amount found in the fresh dill herb. The corresponding values were $7.5 \%$ ( $\alpha$-phellandrene) and $3.5 \%$ (benzofuranoid) in the case of the dill products with the lower moisture content (sample 2, see Table 1). Low retention values for $\alpha$-phellandrene and the benzofuranoid, $2.6 \%$ and 1.8 , respectively, were noticed in freeze dried dill by Drawert et al. (1981). For freeze drying, processing conditions apparently markedly affect the retention of aroma compounds.

Since the volatility of the aroma compounds is different, the losses are selective (Table 3), hence the flavour of the product is not only attenuated but also qualitatively modified.

Moreover, the formation of secondary aroma compounds during processing may alter the flavour of the products. Thus, especially, in the process of freeze drying dill, high amounts of phytadienes are produced (Table 3). The major component, neophytadiene, is present in small amounts already in the fresh dill herb as found also earlier by SCHREIER et al. (1981). However, during freeze drying its amount increased nearly 30 -fold. In fact, neophytadiene was one of the major components $(20-30 \%)$ of freeze dried dill volatiles. Also the amounts of the two other phytadiene isomers arose 20 -fold in freeze drying. Similar enrichment of neophytadiene was found by DRAWERT et al. (1981) during 
freeze concentration of the dill herb extract.

It is obvious that the precursor of the phytadienes is chlorophyll, which is quite easily hydrolysed, liberating phytol (ArONOFF, 1966, Clydesdale and Francis, 1976). On the other hand, phytol is a labile compound, which is dehydrated by mild catalytic action of acids and basis to mixtures of phytadienes (Blumer and Thomas, 1965, De Leeuw et al., 1975). Van de MeEnt et al. (1977) reported formation of phytadienes during freeze drying of sediment samples as a result of claycatalyzed dehydration.

In the hot air drying of dill the three phytadiene isomers were also formed, but in smaller amounts than in freeze drying. Anyhow neophytadiene is one of the main components in addition to $\alpha$-phellandrene in the volatiles of air dried dill products. However, if the sum of the all volatiles identified in the air dried dill products is calculated as percentage of the total volatiles, only $45-58 \%$ is obtained compared to the value of $91 \%$

\section{References}

Aronoff, S. 1966. In The Chlorophylls. Eds. L.P. Vernon \& G.R. Seeley. Academic Press. New York.

Blumer, M. \& Thomas, D.W. 1965. Phytadienes in Zooplankon. Science. 147: 1148-1149.

Byron, G.S. 1982. The drying of laurel leaves. Perfum. Flavor. 7: 37-40.

Clydesdale, M.F. \& Francis, F.J. 1976. Pigments. In Food Chemistry, Part I. p. 385-426. Ed. O.R. Fennema. Marcel Dekker. New York.

DE Leeuw, J.W., Simoneit, B.R., Boon, J.J., RiJPSTRA, W.I.C., DE Lange, F., Leeden, J.C.W., Correia, V.A., Burlingame, A.L. \& Schenck, P.A. 1975. Phytol derived compounds in the geosphere. In Advances in organic chemistry. p. 61-79. Eds. R. Campos \& J. Goni. John Wiley \& Sons. New York.

Drawert, F., Schreier, P., Bhiwapurkar, S. \& Heindze, I. 1981. Chemical-technological aspects for concentration of plant aromas. In Flavour 81 '. p. 649-663. Ed. P. Schreier. Walter de Gruyter. Berlin.

Huopalahtı, R., Kallio, H., Kärppā, P. \& Linko, R. 1981. Comparison of two isolation procedures for aroma compounds of dill. In Flavour 81'. p. 369-376. Ed. P. Schreier. Walter de Gruyter. Berlin.

Huopalahti, R. \& Linko, R. 1983. Composition and content of aroma compounds in dill, Anethum gra- found in the fresh dill herb (Table 3). This indicates that over $50 \%$ of the air dried dill volatiles, including phytadienes, are formed during the drying processes and belong evidently to secondary aroma compounds. Similarly calculated the relative amount of secondary aroma compounds is also over $50 \%$ in the freeze dried dill, although in this case in contrast to the air dried products, the major part of them is composed of phytadienes.

On the basis of the present results it can be concluded that a severe loss of the most important aroma components in the dill herb occurs during hot air drying. Somewhat better retention of aroma compounds was found in freeze drying. By controlling carefully the process conditions, e.g. the freezing and drying rates, the aroma retention can be improved. However, the main problem in the quality of the freeze dried products remains to be the formation of the secondary aroma compounds, especially the phytadienes.

veolens L., at three different growth stages. J. Agric. Food Chem. 31: 331-333.

HuOPALAhtI, R. 1985 a. Gas chromatographic and sensory analyses in the evaluation of the aroma of dill herb, Anethum graveolens L. Lebensm. Wiss. Technol. in press.

Huopalahti, R. 1985 b. The content and composition of aroma compounds in three different cultivars of dill, Anethum graveolens L. Z. Lebensm. Unters. Forsch. in press.

HuOPAlahtı, R. 1985 c.. Dill aroma and its changes during the storage in two kinds of frozen bags. In Progress in flavour research 1984. p. 309-315. Ed. J. Adda. Elsevier. Amsterdam.

Karawya, M.S., EL-WAKEIL, F.A., Hifnawy, M.S., IsMAIL, F.A. \& Khalifa, M.Y. 1980. Study of certain factors affecting yield and composition of herb parsley essential oil. Egypt. J. Pharm. Sci. 21: 69-75.

SCheffer, J.J.J., Koedam, A., Schosler, M. TH.I.W. \& Baerheim, SvendSen, A. 1977. Improved gas chromatographic analysis of naturally occurring oxygencontaining monoterpenes following prefractionation by liquid-solid chromatography. Chromatographia. 10: $669-677$.

Schmidt, W.L. 1975. (McCormick \& Co) Personal 
communication. ref. E.W. Murphy, A.C. Marsh \& B.W. Willis. 1978. Nutrient content of spices and herbs. J. Amer. Diet. Ass. 72: 14-176.

Schreier, P., Drawert, F. \& Heindze, I. 1981. The quantitative composition of natural and technologically changed aromas of plants. VIII. Volatile constituents of fresh dill herb, Anethum gravelons L. Lebensm. Wiss. Technol. 14: 150-152.

VAN DE Meent, D., Maters, W.L., DE Leeuw, J.W. \& SCHENCK, P.A. 1977. Formation of artifacts in sed-

\section{SELOSTUS}

\section{Kuumailma- ja pakkaskuivatuksen vaikutus tillin haihtuviin yhdisteisiin}

\author{
Rainer Huopalahti, Eila Kesälahti ja \\ Reino Linko \\ Kemian ja biokemian laitos/ \\ Elintarvikekemian laboratorio, \\ Turun yliopisto, 20500 Turku
}

Työssă tutkittiin kuumailma- ja pakkaskuivatuksen vaikutusta lehtitillin (Anethum graveolens L.) haihtuviin yhdisteisiin. Tuoreesta ja kuivatuista tillinäytteistä tunnistettiin 25 yhdistettä kaasukromatografia-massaspektrometrian avulla, mutta kuivatusten vaikutusta seurattiin 16 pitoisuudeltaan suurimman yhdisteen osalta. Aromiaineiden päăkomponentit olivat $\alpha$-fellandreeni, 3,6-dimetyyli-2,3,3a,4,5,7a-heksahydrobentsofuraani, $\beta$-fellandreeni, limoneeni, $\alpha$-pineeni, p-symeeni ja myristisiini. Yhdisteiden pitoisuudet văhenivăt huomat- iments upon freeze drying. Org. Geochem. 1: 7-9.

Zaussinger, A. 1975. Die Trocknung von Petersilie, Schnittlauch und Dille mit Hochfrequenzenergie. In Engineering and Food Quality. Proceedings of the 6th European Symposium-Food, Cambridge, United Kingdom, 8-10 September, 1975: 62-71.

Ms received February 15, 1985 tavasti kuivatuksen johdosta. Lehtitillin aromin kannalta tärkeimmän yhdisteen, bentsofuraanijohdannaisen, mảărästă oli kuumailmakuivatuissa tillinäytteissă jäljellä vain hivenmäăristä $1 \%$ :iin ja pakkaskuivatuissa näytteissä 3.5-20 \%:a. Kuivatuksen aikana muodostui ns. sekundaarisia aromiaineita käsittäen yli $50 \%$ :a haihtuvista yhdisteistä. Näistä fytadieenien, erityisesti neofytadieenin osuus oli suuri. Paras tulos, vain noin neljännes tuoreen tillin kokonaisaromimaaărăstă, saavutettiin pakkaskuivatuksella. 